\title{
Dispersal of Aphytis melinus (Hymenoptera: Aphelinidae) after augmentative releases in citrus orchards
}

\author{
Lucia ZAPPALÀ ${ }^{1}$, Orlando CAMPOLO ${ }^{2}$, Saverio Bruno GRANDE², Francesco SARACENO ${ }^{3}$, Antonio BiONDI ${ }^{1}$, \\ GAETANO SISCARO ${ }^{1}$ and VINCENZO PALMERI ${ }^{2}$
}

\author{
${ }^{1}$ Department of Agri-food and Environmental Systems Management, University of Catania, via Santa Sofia 100, 95123 Catania, \\ Italy; e-mails: lzappala@unict.it; antonio.biondi@unict.it; gsiscaro@unict.it \\ ${ }^{2}$ Department of Agricultural and Forest Systems Management, University of Reggio Calabria, loc. Feo di Vito, 89122 Reggio \\ Calabria, Italy; e-mails: orlando.campolo@unirc.it; saverio.grande@unirc.it; vpalmeri@unirc.it \\ ${ }^{3}$ Sicilian Regional Food and Agriculture Assessorship, Department of Structural Intervention in Agriculture, Plant Protection Serv ice \\ U.O. 42, Via Sclafani 34, 95024 Acireale (CT), Italy; e-mail: fsaraceno@regione.sicilia.it
}

Key words. Aphelinidae, California red scale, biological control, parasitoid, flight range, spatial interpolation

\begin{abstract}
The efficacy of natural enemies in controlling pests under field conditions is largely correlated with their capacity to spread within infested crops. In this study the spatial dispersal of the California red scale parasitoid Aphytis melinus DeBach (Hymenoptera: Aphelinidae) was evaluated in the field after augmentative releases. The experiment was conducted in 2007 in six 1-ha plots in a Sicilian citrus orchard under integrated pest management. A total of 180,000 A. melinus adults was released in each of three plots and the other plots were left as untreated control. The flight range of the parasitoid was evaluated, for 35 days after the release, on 16 trees per each plot, located at 20 and $40 \mathrm{~m}$ from the central release point using yellow sticky traps activated with Aonidiella aurantii (Maskell) (Hemiptera: Diaspididae) sexual pheromone and by monitoring the percentage parasitism of the scale on fruits and twigs. The effects of the distance from the release point and density of susceptible stages of host on parasitoid dispersal were evaluated. The number of wasps captured during the whole trial was greater in the traps located $20 \mathrm{~m}$ from the release point than in those at $40 \mathrm{~m}$ and in the control plots. Aphytis melinus dispersed over distances less than $40 \mathrm{~m}$ based on both the lower percentage parasitism and numbers captured recorded at distances of $40 \mathrm{~m}$. The results are discussed in the context of the biological control of California red scale in citrus orchards by means of wasp releases. In particular, the release points should be no more than $40 \mathrm{~m}$ apart for a quick and homogeneous colonization of the area treated.
\end{abstract}

\section{INTRODUCTION}

Knowledge of the mobility and dispersal capacity of entomophagous arthropods is essential for the implementation of biological control strategies. In augmentative programs, when the aim is a quick effect of a mass release of natural enemies rather than their establishment, beneficials must move from the release points and spread throughout the infested area (Corbett \& Rosenheim, 1996). However, a high tendency to disperse could lead to ineffective control (Hougardy \& Mills, 2006). In addition to having a knowledge of the dispersal abilities of biocontrol agents it is also important to know how effective they are at recolonizing crops from untreated surroundings after planting or harvesting and especially after pesticide applications (Desneux et al., 2005, 2007; Langhof et al., 2005). Despite the importance of the distribution of natural enemies for biological control, there are few studies on the dispersal behaviour of biocontrol agents, mainly because it is difficult to measure the dispersal ability of small insects (Hougardy \& Mills, 2006; Tabone et al., 2010). The techniques used up to now rely on recording parasitism percentage on natural or artificial hosts, capture numbers on sticky traps or on glue-sprayed plants and/or by using mark-recapture (Keller et al., 1985; Corbett \& Rosenheim, 1996; Suverkropp et al., 2009; Yu et al., 2009).
In addition, one of the attributes of effective natural enemies is their ability to aggregate spatially in response to the patchy distributions of their hosts, which results in female parasitoids spending more time and/or concentrating in areas where hosts are more abundant (Sanchez et al., 2009). Thus many authors assumed that an aggregative response would increase the parasitoids foraging efficiency and lead to direct density-dependent parasitism and regulation of the host population (Hassell \& May, 1974; Heads \& Lawton, 1983; Stiling, 1987). However, in several cases it was shown that spatial aggregation of parasitism in response to local host density is not a necessary condition for stability or for successful biological control (Reeve \& Murdoch, 1985) and that inverse density dependent and density-independent patterns of parasitism may also be potential stabilizing mechanisms if the distribution of parasitism is sufficiently aggregated (Morrison \& Strong, 1980; Murdoch et al., 1985; Stiling, 1987; van Veen et al., 2002). Therefore, the dispersal and host-location behaviour of wasps, especially released ones, are factors that clearly influence the efficiency of biocontrol (Suverkropp et al., 2009; Tabone et al., 2012). The patterns of distribution vary between species and are also influenced by release conditions and physical factors such as wind, temperature and vegetation structure. Wind 
in particular seems to be an important factor for minute parasitic Hymenoptera (Corbett \& Rosenheim, 1996).

In this study the ability of the parasitic wasp Aphytis melinus DeBach (Hymenoptera: Aphelinidae) to disperse in a citrus orchard was investigated. This parasitoid is important in controlling California red scale, Aonidiella aurantii (Maskell) (Hemiptera: Diaspididae), (Sorribas \& Garcia-Marí, 2010) also by means of augmentative releases (Moreno \& Luck, 1992). This scale is considered one of the most important pests of citrus in the Mediterranean basin as well as in other citrus growing areas worldwide (Jacas et al., 2010). It attacks all aerial parts of the tree including twigs, leaves, branches and fruit. Heavily infested fruit may be downgraded in the packinghouse and, if population levels are high, trees can be seriously damaged. Aphytis melinus effectiveness could depend on the scale careful monitoring, on the use of selective insecticides to control other pests (Grafton-Cardwell et al., 2006; Suma et al., 2009; Planes et al., 2012; Vanaclocha et al., 2012), on the host instars available and their size (Luck \& Podoler, 1985; Pekas et al., 2010a), on ant activity (James et al., 1997; Pekas et al., 2010b), on the fitness of the released insects (Vasquez \& Morse, 2012) or on environmental conditions (DeBach \& Sisojevic, 1960).

The aim of this work was to evaluate the dispersal ability of released $A$. melinus adults and the spatial pattern of parasitism, using $A$. aurantii pheromone yellow sticky traps and scoring percentage parasitism on infested twigs and fruit. Using these methods has the advantage of providing both qualitative and quantitative data on the wasp's presence and distribution in space. The density of the host, the spatial distribution of adult and pre-immaginal stages of both host and parasitoid and the percentage of parasitism are reported. The ability of $A$. melinus to disperse in the field was poorly studied in the past (Samways, 1986) or only over a period of several generations (Campbell, 1976). A good knowledge of its dispersal ability is particularly relevant considering the extremely patchy distribution of the host species (Meats \& Wheeler, 2010) as well as A. melinus poor ability to disperse and short adult life (Rosen \& DeBach, 1979; Samways, 1986; Heimpel et al., 1997). The results obtained are discussed in the context of biological control with specific reference to the ability of $A$. melinus to disperse after augmentative releases in citrus orchards.

\section{MATERIAL AND METHODS}

\section{Experimental field}

The trial was carried out in June-July 2007 in a citrus orchard under integrated pest management located at Lentini (province of Siracusa, Italy) $\left(37^{\circ} 20^{\prime} 34^{\prime \prime} \mathrm{N} ; 14^{\circ} 49^{\prime} 44^{\prime \prime} \mathrm{E}\right)$ at $80 \mathrm{~m}$ above sea level, where no chemical treatments had been applied for three years prior to the trial. The trees in the experimental field were 20 year-old blood orange trees (cv Tarocco, clone Sciré) planted in a 5 by $5 \mathrm{~m}$ grid. The trial was conducted in six 1-ha plots, about $500 \mathrm{~m}$ from each other and with the same climatic, agronomic and orographic features, i.e. shape of the plots, sun exposure, location and gradient (Fig. 1).

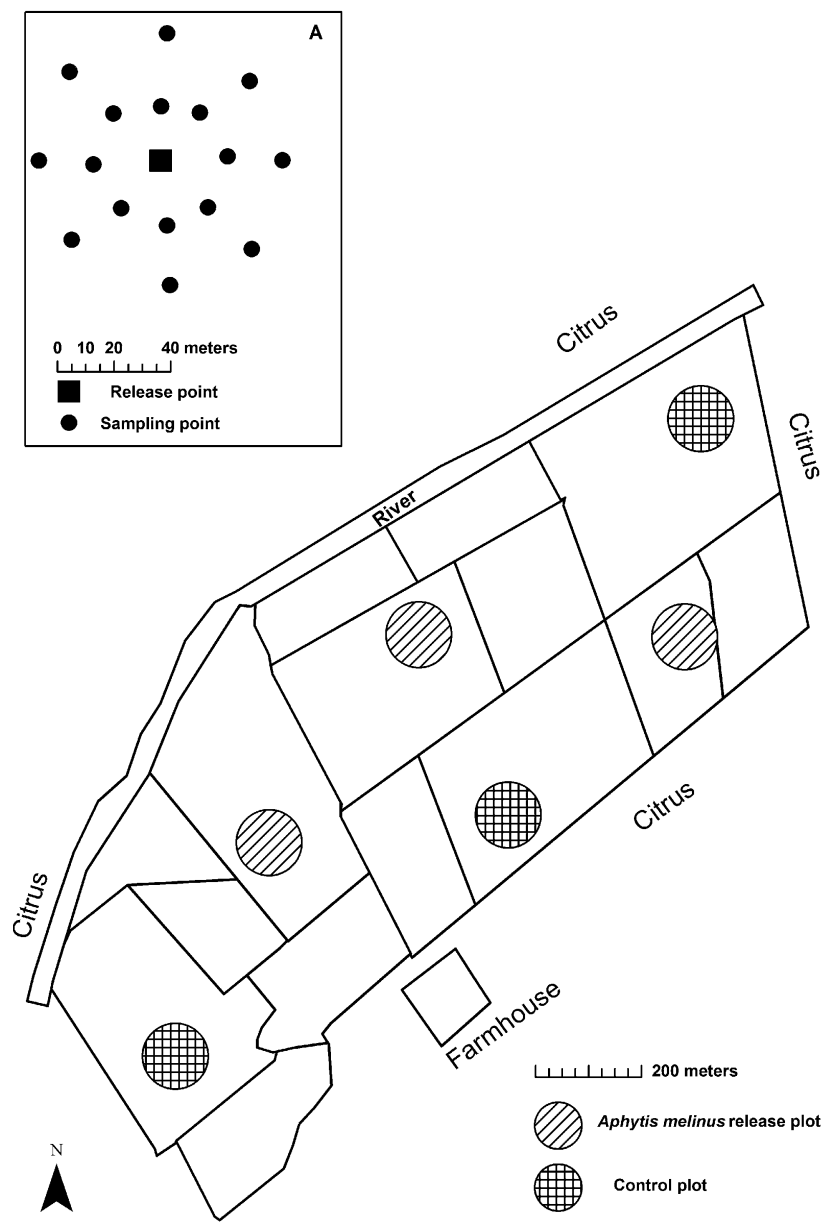

Fig. 1. Outline of the positions of the experimental fields in the surrounding landscape. The location of the trees sampled around the central release point is shown in box (A).

\section{Insect releases}

The wasps used in the experiment were reared at the Sicilian Regional Insectary on a parthenogenetic strain of oleander scale, Aspidiotus nerii Bouché (Hemiptera: Diaspididae), fed on squash (Cucurbita maxima Duch. var. Butternut) (Raciti et al., 2003). In order to keep background parasitism by naturally occurring A. melinus low, the trial was carried out in a period (June-July) when the parasitoid is scarce in the field (Lizzio et al., 1998; Siscaro et al., 1999) and California red scale is mainly present as virgin females, which is the preferred instar of the parasitoid (Luck \& Podoler, 1985; Heimpel et al., 1997; Pekas et al., 2010a).

In each of the three treated plots, 180,000 A. melinus adults were released on the central tree on a single date, while the other plots were used as untreated controls (Fig. 1). This number of A. melinus adults is usually released annually per hectare spread over several dates in spring, early summer and autumn (Moreno \& Luck, 1992; Zappalà et al., 2008). The adult parasitoids released were less than $48 \mathrm{~h}$ old, collected by anesthetizing them using $\mathrm{CO}^{2}$, and the number quantified based on a volume estimation (DeBach \& White, 1960; Raciti et al., 2003). They were then divided up and groups of 5,000 adults were placed in $150 \mathrm{ml}$ vials. These were then carried to the field in a refrigerated box and hung on the central tree for the release. 


\section{Sampling}

Coloured traps attract A. melinus adults (Moreno et al., 1984, Sorribas \& Garcia Mari, 2010). In addition, although several studies show that the recognition and acceptance of $A$. aurantii as host by $A$. melinus is mainly based on a contact, non-volatile kairomone (Hare et al., 1993; Morgan \& Hare, 1998), others indicate that $A$. melinus females are also attracted to airborne cues from hosts, i.e. California red scale virgin females and host-infested fruit (Sternlicht, 1973; Bernal \& Luck, 2007) Therefore, A. aurantii pheromone traps, as well as several colour traps, are known to be effective in capturing Aphytis parasitoids (Sternlicht, 1973; Samways, 1988; Sorribas et al., 2010). In our experiment, the flight range of the parasitoid was evaluated using yellow sticky traps activated with A. aurantii sexual pheromone consisting of minute quantities of (3S,6R)-3methyl-6-(1-methylenenyl)-9-decenyl acetate and (3S,6R)-3methyl-6-(1-methylenenyl)-3,9-decadienyl acetate (Roelofs et al., 1977) impregnated into a pharmaceutical grade natural rubber controlled release medium (AgriSense Ltd., Pontypridd, UK).

The traps were placed in the South-Eastern outer part of the canopy, about $180 \mathrm{~cm}$ above the ground on 16 trees per plot forming circles around the central tree at two distances (20 and $40 \mathrm{~m}$ ) both in release and control plots (see Fig. 1A for a map of the trees sampled). There were six weekly trapping periods, the first just before the release and the others over the following 35 days. The traps and the pheromone dispensers were renewed weekly. The old traps were collected, placed inside transparent plastic bags and taken to the laboratory, where the numbers of Aphytis spp. adults were counted under a stereomicroscope. These were ascribed to A. melinus because this is by far the most abundant species in the study area (Lizzio et al., 1998; Siscaro et al., 1999) and because of the great numbers that were released. In order to assess parasitism both in the release and control plots, 4 fruits per tree (one from each cardinal direction) and 1 to 2 year-old twigs ( $40 \mathrm{~cm}$ in length from each cardinal direction) were randomly collected $150-200 \mathrm{~cm}$ above the ground every week on the same 16 trees on which the traps were hung. In the laboratory, the number of live and ecto-parasitized scales in these samples were scored (see Data analysis section for details).

The wind speed and direction, $2 \mathrm{~m}$ above the ground, were recorded throughout the period of the study along with the temperature and relative humidity by a CR10 Measurement and Control Module, equipped with a 03002-L Wind Sentry Set and CS215 temperature and relative humidity sensor (Campbell Scientific, Inc. Logan, UT USA) located in the experimental field.

\section{Data analysis}

The estimated percentage parasitism (EPP) was measured using the following formula:

$$
\mathrm{EPP}=100 \times(\mathrm{Np} / \mathrm{Nl}+\mathrm{Np})
$$

where $\mathrm{Np}$ is the number of scale instars bearing A. melinus eggs, larvae and/or pupae and $\mathrm{Nl}$ is the number of live $A$. aurantii instars that are suitable hosts for this parasititoid, i.e. second instar (males and females), third instar virgin females and male prepupae (Rosen \& DeBach, 1979; Reeve \& Murdoch, 1986).

The EPP, as well as the number of vulnerable hosts and A. melinus captured, recorded at the two distances from the central tree in the release and control plots, were subjected to a one-way ANOVA. Raw data that did not pass the KolmogorovSmirnov test for normality and the Levene test for equality of variances were subjected to angular or square-root transformation before being analyzed and means were separated using LSD test at $\mathrm{P}<0.05$.

Correlation analysis was used to assess the relationship between the numbers of $A$. melinus captured and EPP during the whole trial and a regression analysis to calculate the dependence of the number of parasitoids captured and EPP on the density of vulnerable stages of $A$. aurantii in the release plot at $20 \mathrm{~m}$ and $40 \mathrm{~m}$ from the release point (SPSS version 19.0, Chicago, IL, USA). The cumulative data of parasitoid captures, EPP and density of vulnerable stages of $A$. aurantii recorded in the five postrelease samples were used for these analyses.

The spatial distribution of $A$. melinus captures and percentage parasitism were calculated using an inverse distance weighted (IDW) interpolation with a power of 1 and a variable search radius with 16 points. Inverse distance weighted methods are based on the assumption that the interpolating surface is influenced more by close than distant points. The interpolating surface is a weighted average of the scatter points and the weight assigned to each scatter point diminishes as the distance from the interpolation point to the scatter point increases. To create the vector and raster map layers of the data, the means of the catches and percentage parasitism recorded on correspondingly located trees in the 3 release plots were used. The analysis was carried out using Surfer Version 8 (Golden software, Golden, $\mathrm{CO}$, USA) with $x, y$ representing the local coordinates and $z$ the fortnightly data, expressed as number of individuals of $A$. melinus trapped and percentage of parasitism.

\section{RESULTS}

\section{Aphytis melinus captures}

The total number of wasps captured during the trial by the circle of traps at $20 \mathrm{~m}$ from the release point, was greater than the numbers captured by the traps at $40 \mathrm{~m}$ and by those in the control plots (Fig. 2). Significant differences in the weekly captures of A. melinus at the different locations were recorded in the pre-release week, and the first $(R+7 d)$, third $(R+21 d)$ and fifth week $(R+$

TABLE 1. Statistical results of the one-way ANOVA used to analyze the effects of the treatments (i.e. $20 \mathrm{~m}$ and $40 \mathrm{~m}$ from the release point and control) on the number of Aphytis melinus captured, on the number of vulnerable hosts and on the estimated percentage parasitism (EPP) recorded in each weekly sampling period.

\begin{tabular}{|c|c|c|c|c|c|c|c|c|c|}
\hline \multirow{2}{*}{ Sampling } & \multicolumn{3}{|c|}{ Aphytis melinus captures } & \multicolumn{3}{|c|}{ Vulnerable hosts } & \multicolumn{3}{|c|}{ EPP } \\
\hline & $F$ & df & $P$ & $F$ & $\mathrm{df}$ & $P$ & $F$ & $\mathrm{df}$ & $P$ \\
\hline Pre-R & 4.98 & 2,93 & $<0.001$ & 1.19 & 2,93 & 0.31 & 0.36 & 2,93 & 0.70 \\
\hline $\mathrm{R}+7 \mathrm{~d}$ & 16.46 & 2,93 & $<0.001$ & 0.22 & 2,93 & 0.80 & 0.09 & 2,93 & 0.92 \\
\hline$R+14 d$ & 0.07 & 2,93 & 0.94 & 5.00 & 2,93 & $<0.001$ & 72.62 & 2,93 & $<0.001$ \\
\hline$R+21 d$ & 23.72 & 2,93 & $<0.001$ & 4.10 & 2,93 & $<0.001$ & 0.09 & 2,93 & 0.92 \\
\hline$R+28 d$ & 1.08 & 2,93 & 0.34 & 8.34 & 2,93 & $<0.001$ & 186.78 & 2,93 & $<0.001$ \\
\hline$R+35 d$ & 32.77 & 2,93 & $<0.001$ & 12.84 & 2,93 & $<0.001$ & 186.78 & 2,93 & $<0.001$ \\
\hline
\end{tabular}




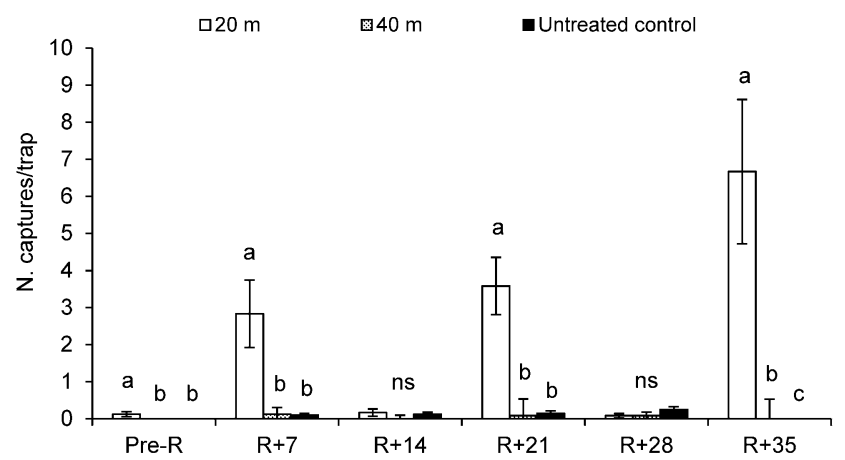

Fig. 2. Mean number of adult Aphytis melinus captured $( \pm \mathrm{SE})$ at $20 \mathrm{~m}$ and $40 \mathrm{~m}$ from the release points and in the controls in each of the six weeks of the study. Columns with different letters in the same time interval are significantly different (ANOVA $P<0.05$ ).

$35 \mathrm{~d})$ after the parasitoid releases. In the second $(\mathrm{R}+14 \mathrm{~d})$ and fourth week $(R+28 d)$ after the release only very few parasitoids were trapped and there were no significant differences in the numbers trapped at the two distances and in the control (Fig. 2; Table 1 for statistical analysis of the results).

\section{Vulnerable hosts}

There were no significant differences in the density of vulnerable hosts in the release and control plots before and 7 days after the release. In contrast, in the following samples the mean number of susceptible hosts per sampled tree was significantly lower in the release plots than in the control plots. However, there were no significant differences in the mean number of susceptible hosts per sampled tree in each of the five weekly samples collected at the two distances in the release plots (Fig. 3; Table 1 for statistical analysis of the results).

\section{Estimated percentage parasitism (EPP)}

Similar to that reported for the density of vulnerable hosts, the EPP by $A$. melinus did not differ significantly in the release and control plots before and 7 days after the

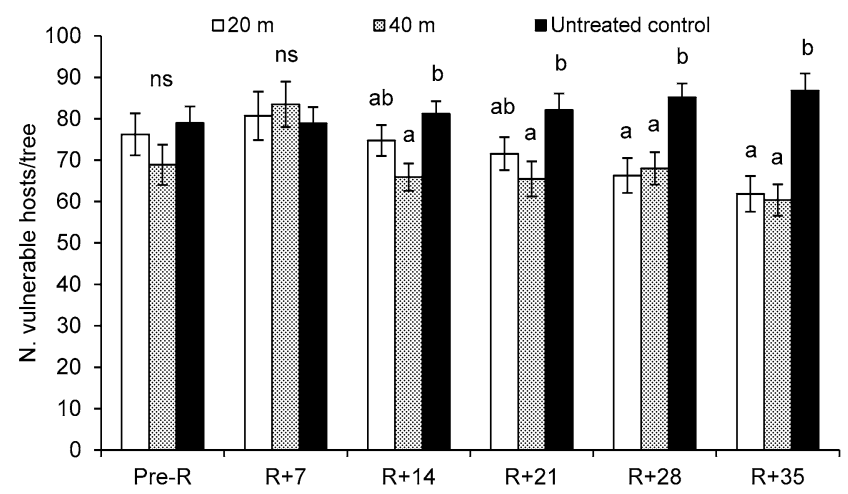

Fig. 3. Mean number $( \pm \mathrm{SE})$ on fruit and twigs of the Aonidiella aurantii instars that are the preferred hosts of Aphytis melinus recorded at $20 \mathrm{~m}$ and $40 \mathrm{~m}$ from the release points and in the controls in each of the six weeks of the study. Columns with different letters in the same time interval are significantly different (ANOVA $P<0.05$ ).

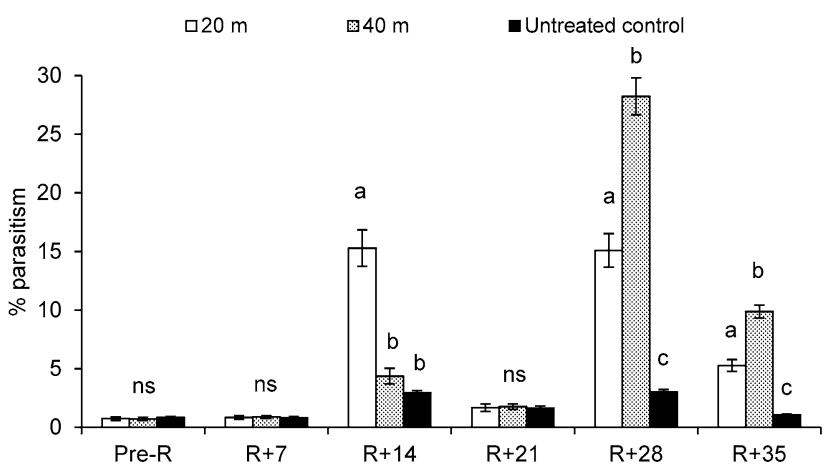

Fig. 4. Mean ( \pm SE) EPP by Aphytis melinus on fruits and twigs recorded at $20 \mathrm{~m}$ and $40 \mathrm{~m}$ from the release points and in the controls in each of the six weeks of the study. Columns with different letters in the same time interval are significantly different (ANOVA $P<0.05$ ).

release. Fourteen days after the release, percentage parasitism was significantly higher in trees located $20 \mathrm{~m}$ from the release point than in the other trees sampled. However, 28 and 35 days after the release the highest percentage parasitism was recorded on the trees located in the circle $40 \mathrm{~m}$ from the release point (Fig. 4; Table 1 for statistical analysis of the results).

\section{Spatial pattern of parasitism}

The cumulative number of A. melinus captured $20 \mathrm{~m}$ from the release point was significantly correlated with EPP $(\rho=0.839 ; \mathrm{N}=48 ; P<0.001)$, but at $40 \mathrm{~m}$ they were not significantly correlated $(\rho=0.686 ; \mathrm{N}=48 ; P=$ $0.61)$. Similarly, the regression analysis showed that the number of parasitoids captured was also dependent on the available host density only in the first circle of trees (20 m) $\left(R^{2}=0.684 ; F=12.97\right.$; d.f. $\left.=1,47 ; P=0.01\right)$ but not in the second $(40 \mathrm{~m})\left(R^{2}=0.053 ; F=0.333\right.$; d.f. $=1,47$; $P=0.585)$. Furthermore, the EPP $20 \mathrm{~m}$ from the release point was significantly related to the density of vulnerable hosts $\left(R^{2}=0.816 ; F=26.662\right.$; d.f. $\left.=1,47 ; P<0.001\right)$ but not at $40 \mathrm{~m}\left(R^{2}=0.371 ; F=3.544 ;\right.$ d.f. $=1,47 ; P=$ 0.109).

The spatial analysis shows that in the 7 days after the releases, more $A$. melinus were caught in the Northern part of all the plots (Fig. 5a). After 21 days more parasitoids were caught in the North and North-Western parts of the plots (Fig. 5c) and after 35 days the distribution of the parasitoid was more uniform but with a high concentration in the Western part (Fig. 5e). After 14 and 28 days the numbers captured was almost zero, mainly because of the life cycle of the released parasitoids, i.e., on these dates, the F1 and F2, respectively, may have been in the larval stages of their life cycle (Fig. 5b, d). As regards percentage parasitism, the distribution recorded 14 days after the release was essentially the same as that of the captures of parasitoids recorded in each of the weekly periods, with the highest values recorded in the Northern part of the plots (Fig. 5f). After 28 days the EPP was more uniform in all the release plots, with no significant concentrations of high percentages, although with higher values $40 \mathrm{~m}$ from the release points (Fig. $5 \mathrm{~g}$ ). 

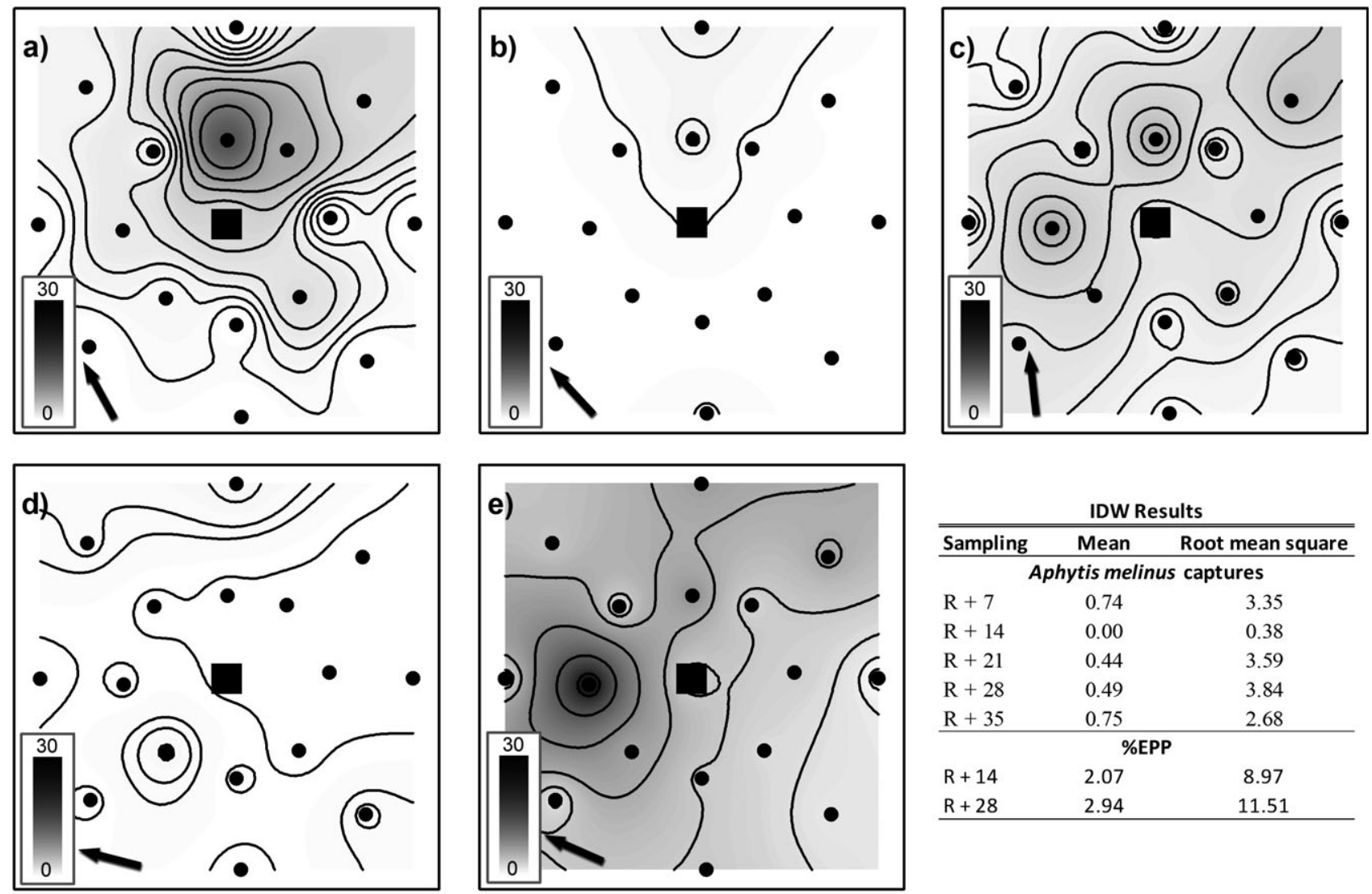

\begin{tabular}{lcc}
\multicolumn{3}{c}{ IDW Results } \\
\hline \hline Sampling & Mean & Root mean square \\
\hline \multicolumn{3}{c}{ Aphytis melinus captures } \\
$\mathrm{R}+7$ & 0.74 & 3.35 \\
$\mathrm{R}+14$ & 0.00 & 0.38 \\
$\mathrm{R}+21$ & 0.44 & 3.59 \\
$\mathrm{R}+28$ & 0.49 & 3.84 \\
$\mathrm{R}+35$ & 0.75 & 2.68 \\
\hline \multicolumn{3}{c}{ \%EPP } \\
$\mathrm{R}+14$ & 2.07 & 8.97 \\
$\mathrm{R}+28$ & 2.94 & 11.51 \\
\hline
\end{tabular}
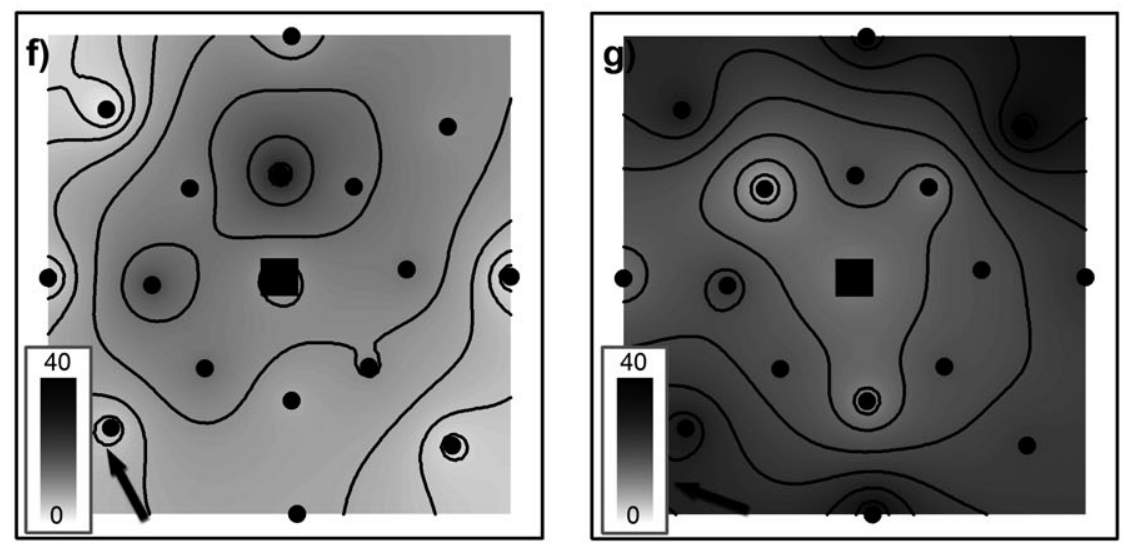

\section{- Release point \\ - Sampling point}

\section{$01020 \quad 40$ meters}

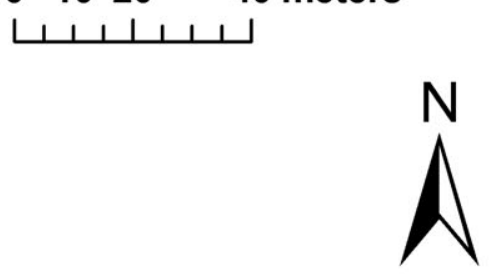

Fig. 5. Contour maps of the numbers of Aphytis melinus captured 7 days (a), 14 days (b), 21 days (c), 28 days (d) and 35 days (e) after the release, and estimated percentage parasitism (\%) recorded 14 days (f) and 28 days (g) after the release (both parameters are indicated by scale in the bottom left corner of each map). The results of the inverse distance weighted (IDW) interpolation are in the table inset below map (c). Black arrows bottom left of each map indicate the mean wind direction in that week.

The mean temperatures and relative humidity recorded during the post-release period were respectively $27.9^{\circ} \mathrm{C}$ and $60.6 \% \mathrm{RH}$. The wind speed, $2 \mathrm{~m}$ above the ground, over the whole trial period averaged $1.9 \mathrm{~m} / \mathrm{s}$ daily, with a mean direction of $141.43^{\circ}$. The pattern in the dispersal of the parasitoids reflects the prevailing wind direction just above the canopy of the trees, at least in the first weeks after the release (Fig. 5). The initial direction of dispersal was influenced by the prevailing wind, while after 35 days the parasitoids were more uniformly distributed, regardless of wind direction. However, the role of wind in determining the distribution of parasitoids in the field and within the canopies of trees needs further study.

\section{DISCUSSION}

The success of many augmentation biocontrol programs depends on the dispersal ability of the natural enemy released (Wright et al., 2001; Kölliker-Ott et al., 2004; Lavandero et al., 2004). However, the optimal dispersal rates of entomophagous species are hard to determine. Low mobility can reduce spread resulting in high levels of control close to the release point and decreasing effectiveness with distance, at least in the first few generations 
after the release. This may imply it is important to have many rather than a few or only one release point in augmentative programs, with consequent increase in cost and high rates of inbreeding. Too high a dispersal rate, on the other hand, might have a negative effect on the population of the beneficial due to an increase in the risk of it failing to find a mate. In other words, the probability of reproduction decreases with increase in dispersal rate, at least in the first generation (i.e. during establishment). Therefore, for augmentative control an intermediate level of dispersal (the so-called "Goldilocks optimum") may maximize establishment and guarantee an effective distribution of the biocontrol agents (Heimpel \& Asplen, 2011).

In this study, A. melinus dispersed progressively from the release point to other citrus trees in the orchard over a period of 35-days. However, they were only uniformly dispersed throughout the study area in the orchard at the end of the trial, when the wasp had completed two generations. Indeed, during the first 14 days after the releases, the parasitoid was mainly recorded only $20 \mathrm{~m}$ from the release point, both in terms of captures and of EPP. In particular, the difference in the number of parasitoids captured in the two treatments (control vs release) during the first 7 days indicates this was mainly due to the release of wasps. The release of adults resulted in an increase in percentage parasitism after a further 7 days $(R$ $+14 \mathrm{~d})$ and a significant decrease in the availability of vulnerable hosts in the release plots compared to the control, and therefore provided a better biocontrol service. The levels of parasitism recorded in the control plots, in the pre-release and $\mathrm{R}+7$ samples, and concomitant very low levels of captures could be due to the attractiveness of susceptible hosts being greater than the pheromone traps for the naturally occurring $A$. melinus. Moreover, our results suggest that the parasitoids that reached the 40 $\mathrm{m}$ circle trees 28 days after the release were the progeny of the released wasps that parasitized hosts within $20 \mathrm{~m}$ of the release point. Indeed, the mean temperature and relative humidity recorded during the post-release period $\left(27.9^{\circ} \mathrm{C}\right.$ and $\left.60.6 \% \mathrm{RH}\right)$ are compatible with this hypothesis, since the duration of immature development of $A$. melinus, under these conditions, ranges between 10 and 13 days, which matches the sampling intervals of our experiment (Yu \& Luck, 1988). The results of this longterm study of the dispersal of parasitoids following their release provide the first step towards determining the theoretically optimal intermediate dispersal level that maximizes the likelihood of establishment and appropriate levels of spread.

The analysis of the potential association between cumulative parasitoid captures and total EPP, and between these two parameters and the density of susceptible hosts, highlighted that host density influenced parasitoid dispersal (in terms of captures and EPP) only at $20 \mathrm{~m}$ from the release points. By contrast, the lack of a significant association at $40 \mathrm{~m}$, between host density, parasitoid presence and activity suggests that, under the infestation conditions recorded in our trial, distance is more important than host availability in determining parasitoid dispersal. The spatial density dependence between percentage parasitism and the population density of hosts is not consistent in host-parasitoid associations in the field. Several studies failed to detect this relationship (Brown \& Cameron, 1979; Stiling \& Strong, 1982; Murdoch et al., 1984), while examples of positive spatial density dependence are provided by other studies (McClure, 1977; Hassell, 1980; Heads \& Lawton, 1983; Lessells, 1985).

As a whole, the low percentage parasitism and the low numbers of $A$. melinus caught in a $35-\mathrm{d}$ period after the release, indicate that the dispersal ability of the wasp is less than $40 \mathrm{~m}$. This should be taken into account in future release programs, in order to increase the rate of colonization, obtain a more uniform and effective distribution of parasitoids and improved pest control. In fact, the percentage parasitism recorded at $40 \mathrm{~m}$ from the release points was statistically higher than in the control plots only 28 days after the release. This finding suggests that the release points should be no more than $40 \mathrm{~m}$ apart (20 $\mathrm{m}$ radius dispersal area), in order to obtain a quick and homogeneous colonization of the whole area treated by released parasitoids. In integrated or biological control programs this is crucial, especially in those using augmentative releases, which rely on high quantities of beneficials enhancing the effect of those naturally present in the field. In addition, a low dispersal ability may disrupt the synchronization between the parasitoid and host cycle, as $A$. melinus prefers to parasitize second instar nymphs or virgin females of $A$. aurantii.

ACKNOWLEDGEMENTS. The authors would like to thank the owners of the "Grimaldi-Xirumi" (Lentini, SR - Italy) farm for permission to carry out this study on their farm, the Sicilian Regional Insectary (B.I.U. - ESA) for providing the parasitoids and the University of Catania for Antonio Biondi's PhD fellowship.

\section{REFERENCES}

Bernal J.S. \& LuCK R.F. 2007: Mate finding via a trail sex pheromone by Aphytis melinus De Bach (Hymenoptera: Aphelinidae) males. J. Insect Behav. 20: 515-525.

Brown M.W. \& CAMERon E.A. 1979: Effect of disparlure and egg mass size on parasitism by the gypsy moth egg parasite, Ooencyrtus kuwanai. Environ. Entomol. 8: 77-80.

Corbett A. \& Rosenheim J.A. 1996: Quantifying movement of a minute parasitoid, Anagrus epos (Hymenoptera: Mymaridae), using fluorescent dust marking and recapture. Biol. Control 6: 35-44.

DeBach P. \& Sisojevic P. 1960: Some effects of temperature and competition on the distribution and relative abundance of Aphytis lingnanensis and A. chrysomphali. Ecology 41: 153-160.

DeBach P. \& White E.B. 1960: Commercial mass culture of the California red scale parasite Aphytis lignanensis. Calif. Agric. Exp. St. Bull. 770: 4-58.

Desneux N., Fauvergue X., Dechaume-Moncharmont F.X., Kerhoas L., Ballanger Y. \& Kaiser L. 2005: Diaeretiella rapae limits Myzus persicae populations after applications of deltamethrin in Oilseed Rape. J. Econ. Entomol. 98: 9-17. 
Desneux N., Decourtye A. \& Delpuech J.M. 2007: The sublethal effects of pesticides on beneficial arthropods. Annu. Rev. Entomol. 52: 81-106.

Grafton-Cardwell E.E., Lee J.E., Stewart J.R. \& Olsen K.D. 2006: Role of two insect growth regulators in integrated pest management of citrus scales. J. Econ. Entomol. 99: 733-744.

Hare J.D., Millar J.G. \& Luck R.F. 1993: A caffeic acid ester mediates host recognition by a parasitic wasp. Naturwissenschaften 80: 92-94.

HAsSELL M.P. 1980: Foraging strategies population models and biological control: a case study. J. Anim. Ecol. 49: 603-628.

Hassell M.P. \& May R.M. 1974: Aggregation of predators and insect parasites and its effect on stability. J. Anim. Ecol. 43: 567-594.

Heads P.A. \& Lawton J.H. 1983: Studies on the natural enemy complex of the holly leafminer: the effects of scale on detection of aggregative responses and the implication for biological control. Oikos 40: 267-276.

Heimpel G.E. \& Asplen M.K. 2011: A “Goldilocks" hypothesis for dispersal of biological control agents. BioControl 56: 441-450.

Heimpel G.E., Rosenheim J.A. \& Kattari D. 1997: Adult feeding and lifetime reproductive success in the parasitoid Aphytis melinus. Entomol. Exp. Appl. 83: 305-315.

Hougardy E. \& Mills N.J. 2006: The influence of host deprivation and egg expenditure on the rate of dispersal of a parasitoid following field release. Biol. Control 37: 206-213.

Jacas J., Karamaouna F., Vercher R. \& Zappalà L. 2010: Citrus pest management in the Northern Mediterranean basin (Spain, Italy and Greece). In Ciancio A. \& Mukerji K.G. (eds): Integrated Management of Arthropod Pests and Insect Borne Diseases. Springer, Dordrecht, pp. 3-26.

James D.G., Stevens M.M. \& O'Malley K.J. 1997: The impact of foraging ants on populations of Coccus hesperidum L. (Hem., Coccidae) and Aonidiella aurantii (Maskell) (Hem., Diaspididae) in an Australian citrus grove. J. Appl. Entomol. 121: $257-259$

Keller M.A., Lewis W.J. \& Stinner R.E. 1985: Biological and practical significance of movement by Trichogramma species - a review. Southwest. Entomol. 8: 138-155.

Kölliker-Ott U.M., Bigler F. \& Hoffmann A.A. 2004: Field dispersal and host location of Trichogramma brassicae is influenced by wing size but not wing shape. Biol. Control 31: $1-10$.

Langhof M., Meyhöfer R., Poehling H. \& Gathmann A. 2005: Measuring the field dispersal of Aphidius colemani (Hymenoptera: Braconidae). Agr. Ecosyst. Environ. 107: 137-143.

Lavandero B., Wratten S., Hagler J. \& Jervis M. 2004: The need for effective marking and tracking techniques for monitoring the movements of insect predators and parasitoids. Int. J. Pest Manag. 50: 147-151.

Lessells C.M. 1985: Parasitoid foraging: should parasitism be density dependent? J. Anim. Ecol. 47: 27-41.

Lizzio S., Siscaro G. \& Longo S. 1998: Analisi dei principali fattori di mortalità di Aonidiella aurantii (Maskell) in agrumeti della Sicilia. Boll. Zool. Agr. Bachic. (Ser. II.) 30: $165-183$.

LuCK R.F. \& Podoler H. 1985: Competitive-exclusion of Aphytis-lingnanensis by Aphytis-melinus - potential role of host size. Ecology 66: 904-913.

McCluRe M.S. 1977: Parasitism of the scale insect, Fiorinia externa (Homoptera: Diaspididae), by Aspidiophagus citrinus (Hymenoptera: Eulophidae) in a hemlock forest: density dependence. Environ. Entomol. 6: 551-555.
Meats A. \& Wheeler S. 2010: Dispersion, contagion, and population stability of red scale, Aonidiella aurantii, in citrus orchards with low or zero insecticide use. Entomol. Exp. Appl. 138: 146-153.

Moreno D.S., Gregory W.A. \& Tanigoshi L.K. 1984: Flight response of Aphytis melinus (Hymenoptera: Aphelinidae) and Scirtothrips citri (Thysanoptera: Thripidae) to trap color, size and shape. Environ. Entomol. 13: 935-940.

Moreno D.S. \& LuCK R.F. 1992: Augmentative releases of Aphytis melinus (Hymenoptera: Aphelinidae) to suppress California red scale (Homoptera: Diaspididae) in Southern California lemon orchards. J. Econ. Entomol. 85: 1112-1119.

Morgan D.J.W. \& Hare J.D. 1998: Volatile cues used by the parasitoid, Aphytis melinus, for host location: California red scale revisited. Entomol. Exp. Appl. 88: 235-245.

Morrison G. \& Strong D.R. 1980: Spatial variations in host density and the intensity of parasitism: some empirical examples. Environ. Entomol. 9: 149-152.

Murdoch W.W., Reeve J.D., Huffaker C.B. \& Kennett C.E. 1984: Biological control of olive scale and its relevance to ecological theory. Am. Nat. 123: 371-392.

Murdoch W.W., Chesson J. \& Chesson P.L. 1985: Biological control in theory and practice. Am. Nat. 125: 344-366.

Pekas A., Agullar A., Tena A. \& Garcia-Marì F. 2010a: Influence of host size on parasitism by Aphytis chrysomphali and A. melinus (Hymenoptera: Aphelinidae) in Mediterranean populations of California red scale Aonidiella aurantii (Hemiptera: Diaspididae). Biol. Control 55: 132-140.

Pekas A., Tena A., Aguilar A. \& Garcia-Marì F. 2010b: Effect of Mediterranean ants (Hymenoptera: Formicidae) on California red scale (Hemiptera: Diaspididae) populations in citrus orchards. Environ. Entomol. 39: 827-834.

Planes L., Catalán J., Tena A., Porcuna J.L., Jacas J.A., IzQuierdo J. \& URBANEJA A. 2012: Lethal and sublethal effects of spirotetramat on the mealybug destroyer, Cryptolaemus montrouzieri. J. Pest Sci. in press doi: 10.1007/s10340-012-0440-3.

Raciti E., Saraceno F. \& Siscaro G. 2003: Mass rearing of Aphytis melinus for biological control of Aonidiella aurantii in Sicily. IOBC/WPRS Bull. 25: 125-134.

ReEve J.D. \& Murdoch W.W. 1985: Aggregation by parasitoids in the successful control of the California red scale: a test of theory. J. Anim. Ecol. 54: 797-816.

Reeve J.D. \& Murdoch W.W. 1986: Biological control by the parasitoid Aphytis melinus, and population stability of the California red scale. J. Anim. Ecol. 55: 1069-1082.

Roelofs W.L., Gieselmann M.J., Cardé A.M., Tashiro H., Moreno D.S., Henrick C.A. \& Anderson R.J. 1977: Sex pheromone of the California red scale, Aonidiella aurantii. Nature 267: 698-699.

Rosen D. \& DeBach P. 1979: Species of Aphytis of the World (Hymenoptera: Aphelinidae). W. Junk, The Hague, 801 pp.

SAmways M.J. 1986: Spatial and temporal population patterns of Aonidiella aurantii (Maskell) (Hemiptera, Diaspididae) parasitoids (Hymenoptera, Aphelinidae and Encyrtidae) caught on yellow sticky traps in citrus. Bull. Entomol. Res.76: 265-274.

SAMways M.J. 1988: Comparative monitoring of red scale Aonidiella aurantii (Mask.) (Hom., Diaspididae) and its Aphytis spp. (Hym., Aphelinidae) parasitoids. J. Appl. Entomol. 105: 483-489.

Sanchez N.E., Pereyra P.C. \& Luna M.G. 2009: Spatial patterns of parasitism of the solitary parasitoid Pseudapanteles dignus (Hymenoptera: Braconidae) on Tuta absoluta (Lepidoptera: Gelechiidae). Environ. Entomol. 38: 365-374. 
Siscaro G., Longo S. \& Lizzio S. 1999: Ruolo degli entomofagi di Aonidiella aurantii (Maskell) (Homoptera, Diaspididae) in agrumeti siciliani. Phytophaga 9: 41-52.

Sorribas J. \& Garcia-Marí F. 2010: Comparative efficacy of different combinations of natural enemies for the biological control of California red scale in citrus groves. Biol. Control 55: 42-48.

Sorribas J., Rodriguez R. \& Garcia-Marí F. 2010: Parasitoid competitive displacement and coexistence in citrus agroecosystems: linking species distribution with climate. Ecol. Appl. 20: 1101-1113.

STERnLicht M. 1973: Parasitic wasps attracted by the sex pheromone of their coccid host. Entomophaga 18: 339-342.

StiLing P.D. 1987: The frequency of density dependence in insect host-parasitoid systems. Ecology 68: 844-856.

Stiling P.D. \& Strong D.R. 1982: Egg density and the intensity of parasitism in Prokelisia marginata (Homoptera: Delphacidae). Ecology 63: 1630-1635.

Suma P., Zappalà L., Mazzeo G. \& Siscaro G. 2009. Lethal and sub-lethal effects of insecticides on natural enemies of citrus scale pests. BioControl 54: 651-661.

Suverkropp B.P., Bigler F. \& van Lenteren J.C. 2009: Dispersal behaviour of Trichogramma brassicae in maize fields. Bull. Insectol. 62: 113-120.

Tabone E., Bardon C. \& Desneux N. 2012: Study of dispersal as a selection criterion for Trichogrammatidae for biological control in cauliflower greenhouses. Acta Hort. 927: 227-236.

Tabone E., Bardon C., Desneux N. \& Wajnberg E. 2010: Parasitism of different Trichogramma species and strains on Plutella xylostella L. on greenhouse cauliflower. J. Pest Sci. 83: 251-256.
Vanaclocha P., Vidal-Quist C., Oheix S., Montón H., Planes L., Catalán J., Tena A., Verdú M.J. \& Urbaneja A. 2012: Acute toxicity in laboratory tests of fresh and aged residues of pesticides used in citrus on the parasitoid Aphytis melinus. $J$. Pest Sci. in press doi: 10.1007/s10340-012-0448-8.

van Veen F.J., Müller C.B., Adriaanse I.C. \& Godfray H.C. 2002: Spatial heterogeneity in risk of secondary parasitism in a natural population of an aphid parasitoid. J. Anim. Ecol. 71: 463-469.

VASQuez C.J. \& Morse J.G. 2012: Fitness components of Aphytis melinus (Hymenoptera: Aphelinidae) reared in five California insectaries. Environ. Entomol. 41: 51-58.

Wright M.G., Hoffmann M.P., Chenus S.A. \& Gardner J. 2001: Dispersal behavior of Trichogramma ostriniae (Hymenoptera: Trichogrammatidae) in sweet corn field: inplications for augmentative releases against Ostrinia nubilalis (Lepidoptera: Crambidae). Biol. Control 22: 29-37.

YU D.S. \& LUCK R.F. 1988: Temperature-dependent size and development of California red scale (Homoptera: Diaspididae) and its effect on host availability for the ectoparasitoid, Aphytis melinus DeBach (Hymenoptera: Aphelinidae). Environ. Entomol. 17: 154-161.

Yu H., Zhang Y., Wu K.M., WyckhuYs K.A.G. \& Guo Y. 2009: Flight potential of Microplitis mediator, a parasitoid of various lepidopteran pests. BioControl 54: 183-193.

Zappalà L., Campolo O., Saraceno F., Grande S.B., Raciti E., Siscaro G. \& Palmeri V. 2008: Augmentative releases of Aphytis melinus (Hymenoptera: Aphelinidae) to control Aonidiella aurantii (Hemiptera: Diaspididae) in Sicilian citrus groves. IOBC/WPRS Bull. 38: 49-54.

Received February 3, 2012; revised and accepted June 20, 2012 